\title{
Effect of Physical Fitness Exercises in 2012 and New Indonesian Gymnastics Exercise (SRIBU) Exercises on Physical Fitness Level of Female Students
}

\author{
Hj. Aminah, AR. Shadiqin, Maruful Kahri \\ Department of Sport and Health Education \\ Universitas Lambung Mangkurat \\ Banjarmasin, Indonesia \\ Aminah_hajjah70@yahoo.com
}

\begin{abstract}
SKJ-2012 is a series of gymnastic movements aimed at improving or maintaining physical fitness launched in 2012. This study aims to determine the effect of the SKJ 2012 and New Indonesian Gymnastics Exercise (SRIBU) exercises on the physical fitness level of female students. The research method used is a quasi-experiment method, with data collection techniques carried out through the initial test, giving treatment as many as $\mathbf{1 6}$ meetings and the final test. The population in this study were female students at SDN Batu Balian 3, aged 10-12 years, as many as 65 people, while the sample in this study were 40 people with a sampling technique using a nonrandom sample technique, namely purposive sampling. The researchers collected the data by using the Indonesian Physical Fitness Test for ages 10-12 years old, physical fitness exercises in 2012, and New Indonesian Ria Gymnastics exercises (SRIBU) and analyzed the data by using T-test. The results showed that first, there was an effect of the 2012 SKJ training on the level of physical fitness for female students at SDN Batu Balian 3. Second, there is the influence of SRIBU training on the level of physical fitness of female students at SDN Batu Balian 3. Third, there is a difference in the effect of the 2012 SKJ and SRIBU exercises on physical fitness levels for female students at SDN Batu Balian 3.
\end{abstract}

Keywords: influence, exercise, SKJ 2012, SRIBU, physical fitness

\section{INTRODUCTION}

Physical education, among others, aims to "develop aspects of physical fitness, movement skills, critical thinking skills," (CDC, 2000; Disman, 1990; Pate and Trost, 1998 in Hanafi, Physical Education Articles). In terms of physiology, physical fitness (Physical Fitness) is the ability and ability of the body to carry out physical loading tasks assigned to it (daily work) without causing significant exhaustion (Moeloek, 1984). For that reason, in 2012, the government launched SKJ 2012 and New Indonesian Ria Gymnastics (SRIBU). SKJ 2012 is a series of gymnastic movements aimed at improving or maintaining physical fitness" (Kemenpora, Director General of Sports, posted by Sugihartono, 2013). New Indonesian Ria Gymnastics (SRIBU) was created "according to the growing needs of children aged 4-13 years, carried out continuously, rhythmically, which involves all parts of the body huge muscles, according to the needs of growth "(Nelly, 2011: 1), but until now the effect on students' physical fitness is still unclear. Although "2012 Physical Fitness Gymnastics (SKJ-2012) and the New Indonesian Ria Gymnastics (SRIBU) are training facilities to improve physical fitness required by the Indonesian government
(Hidayat: 1996 in Pupin: 2013: 1), but most students do not yet have proper fitness, this is seen in the motivation of students when PBM takes place. Thus the influence of SKJ2012 and SRIBU on physical fitness still needs to be studied in more depth.

Various realities are likely to be obstacles to the achievement of the objectives of the 2012 SKJ-giving and SRIBU. First, not all pubic elementary school (SDN) physical buildings in South Kalimantan have playgrounds to support PBM PJOK, even though facilities such as open fields must be available for activities (RI Law No. 3 of 2005 article 67 paragraph 1). Second, not all Physical Education teachers in elementary schools have the knowledge and skills of SKJ2012 and SRIBU. Third, until now, the Department of Education has never provided training for Physical Education teachers, as a form of concern for the physical fitness of students. Fourth, a database on the physical fitness of students at the elementary school level in South Kalimantan has never been published. Fifth, it is probable that a study of the effect of giving one of the exercises to the level of physical fitness of students has never been done, and there have been no reports. Sixth, it is necessary to understand the fundamental for every teacher and principal, that physical fitness is related to student learning achievement (Mukholid, 2004: 3).

Handoko (2012) states that "besides IQ, the contribution of the level of physical fitness to learning achievement is enormous or reaches $62.2 \%$." Based on this study, the physical fitness of students must always be maintained and improved. It means that the factors directly affect the physical fitness of learners must get the attention of all principals as well as all teachers at the school. If this problem is left, then our hope in students who have healthy growth and development will experience developmental disorders. In order to avoid scarcity of data and omission of these conditions, it is necessary to immediately conduct an in-depth assessment of the two gymnastics models to determine the effect of SKJ-2012 and SRIBU on the level of physical fitness of learners. To ensure the presence or absence of the influence mentioned above can be conducted experiments on students who have previously conducted a preliminary study to get a homogeneous sample. SKJ-2012 and SRIBU are independent variables that will be tested for their effect on the level of physical fitness after each group experiences treatment. Thus the general aim of the study is to find out which exercises are most effective in increasing the physical fitness of students at the elementary school level. 
Based on the description above, it is necessary to take concrete action to determine the effect of SKJ-2012 and SRIBU on the level of physical fitness. The difference in the length of time of the SKJ-2012 and SRIBU exercises in the field may be the basis for the difference in influence between the two gymnastic models. Following the purpose of the research to be known, the researchers plan to conduct an experiment that will examine the "Differences in the Effects of SKJ-2012 Exercise with SRIBU on Physical Fitness Levels in Female Students in SDN Batu Balian 3 2015/2016 Academic Year".

\section{METHOD}

This study uses a quasi-experimental method, with subjects female elementary school students aged 10-12 years with average physical fitness status "moderate" (preliminary observations). The determination of the experimental group 1 and the experimental group 2, based on the even-odd method (split) on a homogeneous sample frame, namely the results of initial measurements with TKJI for ages 10-12 years. The researchers gave the 2012 SKJ exercise to experimental group 1, and New Indonesian Gymnastics Exercise (SRIBU) to experimental group 2. The treatment in both groups was carried out two times a week and lasted for six weeks. They collected the data by using the Indonesian Physical Fitness Test for ages 10-12 years old, physical fitness exercises in 2012 and New Indonesian Ria Gymnastics exercises (SRIBU) and analyzed by Data analysis using the Hypothesis Test with a test (T-test) results that can reject the null hypothesis, and accept alternative hypotheses.

\section{RESULTS AND DISCUSSION}

The results of the data obtained in the field: 1) pretest data on the level of physical fitness for female students of SDN Batu Balian 3 in the 2012 SKJ training group obtained an average of 15.50 ; with the highest score of 17 and the lowest score of $14 ; 2$ ) posttest data on physical fitness level for female students at SDN Batu Balian 3 in the 2012 SKJ training group obtained an average of 19.55; with the highest score of 23 and the lowest score of $23 ; 3$ ) pretest data on the level of physical fitness of female students at SDN Batu Balian 3 SRIBU training groups obtained an average of 15.45; with the highest score of 17 and the lowest score of 14; and 4) posttest data on physical fitness level for female students of SDN Batu Balian 3 SRIBU training groups obtained an average of 18.10; with the highest score of 16 and the lowest score of 21 . The data above clearly shows that there is an increase in the average before treatment and the average after treatment, this shows that the 2012 SKJ training and SRIBU training can increase the level of physical fitness in female students at SDN Batu Balian 3.

Based on the results of statistical analysis with the t-test as presented in the table above as follows; 1 ) the results of the ttest analysis of pretest variable with posttest physical fitness level on female students of SDN Batu Balian 3 SKJ 2012 training group, obtained $\mathrm{t}$-count $=18.136>\mathrm{t}$-table $(19 ; 0.025)$ $=2.09$, or with Sig. (2-tailed ) $=0,000$; it turns out that Sig. (2tailed) $=0,000<0.05$ thus the $\mathrm{t}$-count is significant. Therefore, it can be concluded that there is an effect of the 2012 SKJ exercise on the level of physical fitness of female students at SDN Batu Balian 3; 2) the results of the t-test analysis of pretest variables with posttest physical fitness levels in female students of SDN Batu Balian 3 SRIBU training group, obtained $t$-count $=15.904>$ t-table $(19 ; 0.025)=2.09$, or with
Sig. $(2$-tailed $)=0,000$; it turns out that Sig. $(2$-tailed $)=0,000$ $<0.05$ thus the t-count is significant. So it can be concluded that there is an effect of SRIBU training on physical fitness level for female students at SDN Batu Balian 3; 3) the results of the t-test analysis of the 2012 SKJ posttest variable with the SRIBU group posttest physical fitness level in female students of SDN Batu Balian 3, obtained t-count $=3.067>\mathrm{t}$-table $(19$; $0.025)=2.09$, or with Sig. (2- tailed) $=0,000$; it turns out that Sig. $(2$-tailed $)=0.020<0.05$ thus the $\mathrm{t}$-count is significant. So it can be concluded that there is a difference in the effect of the 2012 SKJ training with SRIBU on the level of physical fitness for female students at SDN Batu Balian 3.

SKJ-2012 and New Indonesian Gymnastics (SRIBU) is a training facility to improve physical fitness required by the Indonesian government (Hidayat: 1996 in Pupin: 2013: 1). Forms of exercise to improve physical fitness status applied in this study are SKJ 2012 exercises and SRIBU exercises. It turns out that the results of the analysis show the following findings. First, there is an effect of SKJ 2012 exercises on the level of physical fitness of female students at SDN Batu Balian 3. Second, there is an influence of SRIBU training on the level of physical fitness in female students at SDN Batu Balian 3. Third, there are differences in the effect of the 2012 SKJ and SRIBU exercises on the physical fitness level of female students at SDN Batu Balian 3. This means that the form of SKJ 2012 and SRIBU exercises can be used in training the physical fitness of students. However, of the two types of exercises better is the 2012 SKJ exercise compared to the SRIBU exercise to improve physical fitness, which has an impact on the physical fitness level for female students at SDN Batu Balian 3. If we compare the two exercises, there are differences; the SKJ-2012 exercise is "a series of gymnastic movements aimed at improving or maintaining physical fitness" (Director General of Sports, posted by Sugihartono, 2013). In addition to the above striking difference is the duration of time in the 2012 SKJ is 14 minutes 58 seconds, while in SRIBU, the duration is 8 minutes 24 seconds. The difference in duration can affect the physical fitness of students. The longer the duration of movement, the faster and higher the physical fitness of students. Gymnastics increases physical fitness has been examined in several studies namely Wismayanti, M. (2013) mentions an increase in physical fitness exercises, in research (Kamajaya, 2013) there is a change in physical fitness in exercise, In a journal (Arifin, 2018) states that gymnastics can improve one's physical fitness.

\section{CONCLUSION}

The conclusion of this study is based on data analysis, hypothesis testing, and discussion that has been done in the previous chapter. First, there is an effect of the 2012 SKJ exercise on the level of physical fitness in female students at SDN Batu Balian 3. Second, there is an influence of SRIBU training on the level of physical fitness in female students at SDN Batu Balian 3. Three, there is a difference in the effect of the 2012 SKJ and SRIBU exercises on the physical fitness level of female students at SDN Batu Balian 3.

\section{ACKNOWLEDGMENT}

We would like to be grateful to the Dean of Teacher Training and Education Faculty, Lambung Mangkurat University, who has supported us in the form of funding. Therefore we could join this International Conference. 


\section{REFERENCES}

[1] Hanafi. 2012 . Teori dan Tujuan Pendidikan Jasmani : Perspektif Pendidikan

[2] Moeloek, D., 2011.a. Pengantar Teori dan Metodologi Melatih Fisik. Penerbit Lubuk Agung Bandung

[3] Nelly, 2013, Panduan gerak SRIBU dan video gerakan. Diunduh tanggal 12 Nopember 2015

[4] Sugihartono,T..2013 . SKJ 2012 Sebagai Pilihan . Artikel Penjas FKIP UNIB
[5] Wismayanti, M. (2013). Pengaruh Hasil Latihan Senam Kebugaran Jasmani 2012 Dan Senam Aerobik Terhadap Peningkatan Kebugaran Jasmani Siswa Putri Kelas VII Smp N 2 Purbalingga Tahun 2013/2014 (Doctoral dissertation, Universitas Negeri Semarang).

[6] Kamajaya, D. M., Dantes, N., \& Kanca, N. (2013). Pengaruh pelatihan senam kesegaran jasmani 2008 terhadap volume oksigen maksimal ditinjau dari kemampuan awal. Jurnal Penelitian dan Evaluasi Pendidikan Indonesia, 3(1).

[7] Arifin, Z. (2018). Pengaruh Latihan Senam Kebugaran Jasmani (Skj) Terhadap Tingkat Kebugaran Siswa Kelas V Di Min Donomulyo Kabupaten Malang. Journal Al-Mudarris, 1(1), 22-29. 